\title{
THREE NEW DC-TO-DC SINGLE-SWITCH CONVERTERS
}

\author{
Barry W Williams ${ }^{1}$, Mona Fouad Moussa ${ }^{2}$ \\ ${ }^{1}$ Department of Electrical and Electronic Engineering, The University of Strathclyde \\ 2Electrical Engineering Department, Arab Academy for Science and Technology and Maritime Transport
}

(AASTMT) Cairo, EGYPT

Barry.Williams@strath.ac.uk,mona.moussa@aast.edu

+ 4401415482386

\begin{abstract}
This paper presents a new family of three previously unidentified dc-to-dc converters, buck, boost, and buck-boost voltage-transfer-function topologies, which offer advantageous transformer coupling features and low capacitor dc voltage stressing. The three single-switch, single-diode, converters offer the same features as basic dc-to-dc converters, such as the buck function with continuous output current and the boost function with continuous input current. Converter time-domain simulations and experimental results (including transformer coupling) support and extol the dc-to-dc converter concepts and analysis presented.
\end{abstract}

Keywords - dc-to-dc converters, switch mode power supplies, dc-to-dc power conversion

\section{INTRODUCTION}

Applications for dc-to-dc converters include dc power supplies for electronic systems, hand-held electronics, portable electronics, electric vehicles, battery chargers [1], [2], systems for the utilization of fuel cell [3]-[5], solar [6]-[8], and wind energy [9], which incorporate super-capacitors [3], smart grids and distributed generation [10]-[13], electronic ballast [14], energy harvesting [15], power factor correction, and dc motor drives. Additionally, these converters form the basic building blocks for other power converter types, plus interleaved or multiphase converters [16]-[19], bidirectional dc-to-dc converters [20]-[23] multiple input converters [24], cascaded output converters [25], [26] and high voltage supplies. Similar to basic dc-to-dc converter analysis [27], with snubbers [28], converters can be controlled in a voltage mode or a current mode [29], [30].

Additional to the basic three converters, viz., buck, boost, and buck-boost converters, there are 27 other (plus three new converters here within) identified single-switch, single-diode transformer-less dc-to-dc converters. In all cases, continuous conduction operation is possible at light loads with two switch/diode combinations, which allow bidirectional inductor current, [2], [20]-[23].

Also, in addition to a switch and diode, the three new dc-to-dc converters incorporate two inductors and two capacitors (as with the Cuk, zeta, -ve Lou, and sepic converters) from which a voltage sourcing output is derived.Operational concepts of three new dc-to-dc converter topologies (with buck, boost, and buckboost transfer functions) are presented, along with component ratings and specifications, circuit simulations, and practical results. For reference purposes, performance and features of the three new converters are compared with the three basic (buck, boost and buck-boost) converters. Experimental results for a transformer coupled version of the new buck-boost topology culminate the paper.

\section{THREE NEW DC-TO-DC CONVERTER TOPOLOGIES}

The three new converter topologies, termed P\#1, $P \# 2$, and $P \# 5$, are shown in figure 1 row cct $P$. The buck-boost topology $\mathrm{P \# 5}$ is derived by an alternative alteration rearrangement of the elements common to the Cuk, sepic, and zeta converters. The buck converter P\#1 has a current source output, being sourced by two inductors $L_{i}$ and $L_{0}$, converted to a voltage source output by the addition of load ac current shunt capacitor $C_{o}$ as shown in figure $1 P(a)$. The boost converter $\mathrm{P \# 2}$ in figure $1 \mathrm{P}(\mathrm{b})$ has continuous input current properties since the input paths comprises two inductors $L_{i}$ and $L_{o}$. The buckboost converter $\mathrm{P \# 5}$ in figure $1 \mathrm{P}(\mathrm{c})$ has discontinuous input and output currents, since a series switching device switches between the input and output circuits. These properties are the same features possessed by the basic three dc-to-dc converters, termed A1 - buck, A2 - boost, and A5 - buck-boost converters in figure 1 row cct $A$ [31], in which all have one inductor less (one rather than two inductors) and no energy transfer capacitor. All converters use shunt output filter capacitor $C_{o}$ to create a voltage sourcing output. 
Figure 1 row cct $\mathrm{P}^{\prime}$ shows the two states created by operation of the switch $T$, namely the current loops when the switch $T$ is on, ton and when $T$ is off, toff, (such that ton+toff $=T=1 /$ fs where fs is the switching frequency). Energy transfer (voltage and current transfer function) analysis is based on the capacitor $C$ voltage ripple $\Delta \mathrm{vc}$, specifically $\mathrm{C} \times \Delta \mathrm{vc}=\int \mathrm{ic} \mathrm{dt}$, (eqn 1 in figure 1), assuming continuous but not necessarily constant current in the two circuit inductors Li and Lo (continuous conduction mode, CCM). Three basic converter transfer functions result, viz., buck, boost, and buck-boost, which are only switch on-state duty cycle ton $/ \mathrm{T}=\delta$ dependent, as shown by eqn 2 in figure 1.
All three new topologies are characterized by a central Kirchhoff voltage loop involving only a capacitor $\mathrm{C}$ and two inductors $\mathrm{Li}$ and Lo. By Kirchhoff's voltage law, the average capacitor voltage is zero, since each of the two inductors has an average voltage of zero. This zero average capacitor voltage is fulfilled by alternating balanced positive and negative charging (positive and negative voltages). Kirchhoff's voltage and current laws can be used to derive the average voltage and current ratings of the various circuit elements, which are summarised in Table I. In Table I the steady-state characterization (for sake of consistency) process makes extensive use of the fact that, in steady state, average inductor voltage $[\mathrm{iL}(0)=\mathrm{i}(\mathrm{T})]$ and average capacitor current $[\mathrm{vc}(0)=\mathrm{vc}(\mathrm{T})]$ are both zero.

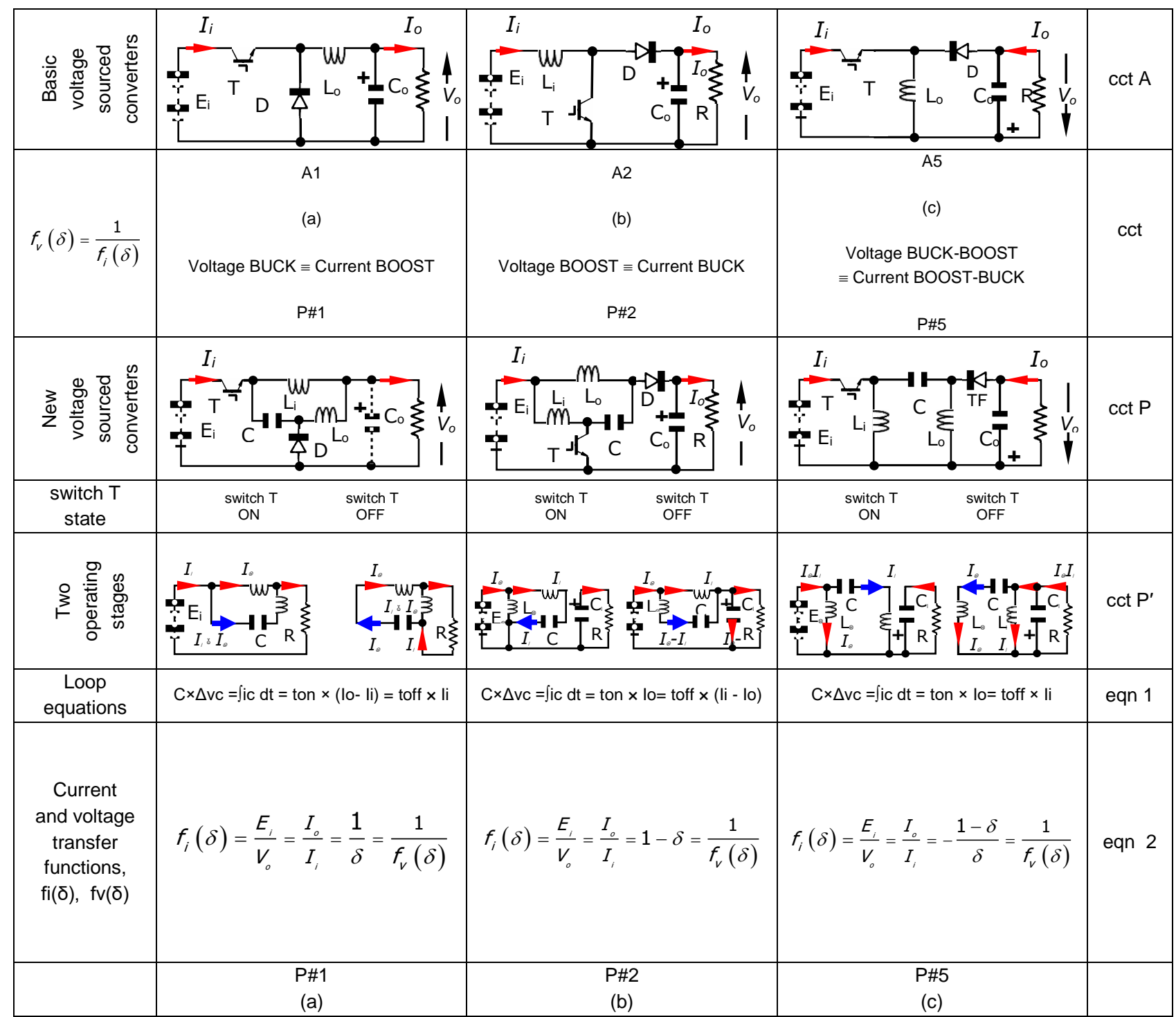

Fig .1. DC-to-dc voltage-sourced topologies, operating stages, and transfer functions. 
Journal of Renewable Energy and Sustainable Development (RESD) Volume 3 Issue 2, June 2017 - ISSN 2356-8569 http://dx.doi.org/10.21622/RESD.2017.03.2.196

Table 1. DC-to-dc converter normalized component ratings

\begin{tabular}{|c|c|c|c|c|c|c|}
\hline \multicolumn{4}{|c|}{ voltage } & Buck & boost & buck-boost \\
\hline \multicolumn{4}{|c|}{ Figure $1 / \mathrm{cct}$} & A (a) & $A(b)$ & $A(c)$ \\
\hline \multicolumn{4}{|c|}{ topology } & P\#1 & $\mathrm{P} \# 2$ & $\mathrm{P} \# 5$ \\
\hline \multirow{2}{*}{ transfer function } & Voltage & $\mathrm{TF}_{\mathrm{v}}$ & $V_{0} / E_{i}$ & $\delta$ & $\frac{1}{1-\delta}$ & $\frac{-\delta}{1-\delta}$ \\
\hline & Current & $\mathrm{TF}_{\mathrm{i}}$ & $\mathrm{I}_{0} / \mathrm{I}_{\mathrm{i}}$ & $1 / \delta$ & $1-\delta$ & $\frac{1-\delta}{-\delta}$ \\
\hline \multirow{4}{*}{$\begin{array}{c}\text { Switch } \\
T\end{array}$} & \multirow{2}{*}{$\begin{array}{c}\mathrm{T} \\
\text { (ave) }\end{array}$} & voltage & $\mathrm{V}_{T} / \mathrm{E}_{\mathrm{i}}$ & $1-\delta$ & 1 & 1 \\
\hline & & current & $I_{T} / I_{0}$ & $\delta^{2}$ & $\delta^{2}$ & $\frac{\delta}{1-\delta}$ \\
\hline & \multirow{2}{*}{$\begin{array}{c}\mathrm{T} \\
(\max )\end{array}$} & voltage & $V_{T} / E_{i}$ & 1 & $\frac{1}{1-\delta}$ & $\frac{1}{1-\delta}$ \\
\hline & & current & $I_{T} / I_{0}$ & 1 & $\frac{1}{1-\delta}$ & $\frac{1}{1-\delta}$ \\
\hline \multirow{4}{*}{$\begin{array}{l}\text { Diode } \\
\text { D }\end{array}$} & \multirow{2}{*}{$\begin{array}{c}\mathrm{D} \\
\text { (ave) }\end{array}$} & voltage & $V_{D} / E_{i}$ & $\delta$ & $\frac{\delta}{1-\delta}$ & $\frac{\delta}{1-\delta}$ \\
\hline & & current & $I_{D} / I_{0}$ & $\delta(1-\delta)$ & 1 & 1 \\
\hline & \multirow{2}{*}{$\stackrel{\mathrm{D}}{(\max )}$} & voltage & $V_{D} / E_{i}$ & 1 & $\frac{1}{1-\delta}$ & $\frac{1}{1-\delta}$ \\
\hline & & current & $I_{D} / I_{0}$ & 1 & $\frac{1}{1-\delta}$ & $\frac{1}{1-\delta}$ \\
\hline \multirow{4}{*}{$\begin{array}{c}\text { Capacitor } \\
\text { C }\end{array}$} & \multirow{2}{*}{ current } & $t_{\text {on }}$ & $I_{c} / I_{0}$ & $1-\delta$ & 1 & 1 \\
\hline & & $T-t_{0 n}$ & $\mathrm{I}_{\mathrm{C}} / \mathrm{I}_{\mathrm{O}}$ & $\delta$ & $\delta$ & $\frac{\delta}{1-\delta}$ \\
\hline & \multirow[b]{2}{*}{ voltage } & average & $V_{c} / E_{i}$ & 0 & 0 & 0 \\
\hline & & ripple & $\begin{array}{l}\mathrm{C} \Delta \mathrm{v}_{\mathrm{C}} / \mathrm{T} \mathrm{l}_{\mathrm{o}} \\
\mathrm{C} \Delta \mathrm{v}_{\mathrm{C}} / \mathrm{T} \mathrm{l}_{\mathrm{i}}\end{array}$ & $\begin{array}{c}\delta(1-\delta) \\
1-\delta\end{array}$ & $\begin{array}{c}\delta \\
\delta(1-\delta)\end{array}$ & $\begin{array}{c}\delta \\
1-\delta\end{array}$ \\
\hline \multirow{5}{*}{$\begin{array}{l}\text { Inductor current } \\
\qquad I_{L}\end{array}$} & \multirow{2}{*}{ average current } & $\mathrm{Li}_{\mathrm{i}}$ & $\begin{array}{l}\mathrm{L}_{\mathrm{L}} / \mathrm{I}_{\mathrm{O}} \\
\mathrm{L}_{\mathrm{L}} / \mathrm{I}_{\mathrm{i}}\end{array}$ & $\begin{array}{l}\delta \\
1\end{array}$ & $\frac{\delta}{1-\delta}$ & $\frac{\delta}{1-\delta}$ \\
\hline & & $\mathrm{L}_{0}$ & $\begin{array}{l}\mathrm{I}_{\mathrm{LO}} / \mathrm{I}_{\mathrm{O}} \\
\mathrm{I}_{\mathrm{LO}} / \mathrm{I}_{\mathrm{i}}\end{array}$ & $\begin{array}{c}1-\delta \\
\frac{1-\delta}{\delta} \\
\end{array}$ & $\begin{array}{c}1 \\
1-\delta\end{array}$ & $\begin{array}{c}1 \\
\frac{1-\delta}{\delta} \\
\end{array}$ \\
\hline & $\begin{array}{c}\text { dc } \\
\text { losses }\end{array}$ & $\begin{array}{c}\mathrm{PL}_{i}+\mathrm{PL}_{0} \\
\mathrm{~L}_{i}=\mathrm{L}_{0}\end{array}$ & $\frac{I_{L i}^{2}+I_{L o}^{2}}{I_{i}^{2}}$ & $\frac{2 \delta^{2}-2 \delta+1}{\delta^{2}}$ & $2 \delta^{2}-2 \delta+1$ & $\frac{2 \delta^{2}-2 \delta+1}{\delta^{2}}$ \\
\hline & \multirow{2}{*}{ ripple current } & $\mathrm{Li}_{\mathrm{i}}$ & $\mathrm{L}_{\mathrm{i}} \Delta \mathrm{I}_{\mathrm{Li}} / \mathrm{TE}_{\mathrm{i}}$ & $\delta(1-\delta)$ & $\delta$ & $\delta$ \\
\hline & & $\mathrm{L}_{0}$ & $\mathrm{~L}_{0} \Delta \mathrm{l}_{\mathrm{Lo}} / \mathrm{TE} \mathrm{E}_{\mathrm{i}}$ & $\delta(1-\delta)$ & $\delta$ & $\approx \delta$ \\
\hline \multirow[b]{2}{*}{$\begin{array}{l}\text { input/output } \\
\text { ripple current }\end{array}$} & input & $\mathrm{I}_{\mathrm{i}}$ & $\mathrm{L}_{\mathrm{i}} \Delta \mathrm{I}_{\mathrm{i}}$ & $\begin{array}{c}\text { discontinuous } \\
0, I_{0}\end{array}$ & $\begin{array}{c}\text { continuous } \\
2 \delta \mathrm{TE}_{\mathrm{i}}\end{array}$ & $\begin{array}{c}\text { discontinuous } \\
0, I_{0} /(1-\delta)\end{array}$ \\
\hline & output & into $C_{0} / / R$ & $L_{0} \Delta \mathrm{I}_{0}$ & $\begin{array}{l}\text { continuous } \\
2(1-\delta) \mathrm{TV}_{0}\end{array}$ & $\begin{array}{c}\text { discontinuous } \\
0, I_{0} /(1-\delta)\end{array}$ & $\begin{array}{c}\text { discontinuous } \\
0, I_{0} /(1-\delta)\end{array}$ \\
\hline
\end{tabular}


$\mathrm{AC}$ wise, $\mathrm{C}$ is a short circuit resulting in $\mathrm{Li}$ and Lo being parallel connected such that each topology in figure 1 cct $P$ reverts (degenerates), for analysis purposes, to the corresponding basic dc-to-dc converter in Figure $1 \mathrm{cct} A$. This paper specifically exploits the benefits gained from zero average capacitor voltage, which are not available with the degenerate basic converters circuits.

From Table I, the average inductor currents ILi and ILo are related to the input and output currents li and Io, and the duty cycle $\delta$. Thus as the load current decreases, the input current decreases, whence the average current of both inductors decreases. As the transferred energy decreases (average input current decreases), the capacitor ripple voltage (eqn 1 in figure 1) which is proportional to output current (energy transfer) decreases. Eventually, with decreasing load current, discontinuous conduction occurs in $\mathrm{C}$, characterized by continuous zero capacitor voltage regions at the end of each switching period.

\section{SIMULATION AND EXPERIMENTAL RESULTS: THREE}

The functionality operation aspects can be initially established by time domain transient analysis. Additionally, component voltage and current stresses can also be assessed, confirming the circuit analysis used to derive the component ratings given in Table I. Table IIA shows the component values and ratings used for both the simulations and the experimentation, although some ideal components (losses capacitors and inductors, no switch and diode switching losses) are assumed in the simulations so as to confirm the theoretical circuit analysis performance values in Table I. Transient analysis simulations were performed using National Instruments, Multisim Power Pro 11.0.1, with user defined initial conditions as shown in Table IIB.

Table 2.A Component values

\begin{tabular}{|c|c|c|c|c|}
\hline Ei & $20 \mathrm{~V}$ & & T, mosfet & $200 \mathrm{~V}, 54 \mathrm{~m} \Omega$ \\
\hline Lo & $\begin{array}{c}1.0 \mathrm{mH}, 74 \mathrm{~m} \Omega, \\
10 \mathrm{~A}\end{array}$ & & $\mathrm{D}, \mathrm{SiC}$ & $600 \mathrm{~V}, 10 \mathrm{~A}$ \\
\hline $\mathrm{Li}$ & $\begin{array}{c}1.0 \mathrm{mH}, 74 \mathrm{~m} \Omega, \\
10 \mathrm{~A}\end{array}$ & & ton , toff & $15 \mu \mathrm{s}, 5 \mu \mathrm{s}$ \\
\hline C & $10 \mu \mathrm{F}$ & & $\delta$ & $75 \%$ \\
\hline Co & $1000 \mu \mathrm{F}$ & $\mathrm{f}$ & $50 \mathrm{kHz}$ \\
\hline
\end{tabular}

Table 2.B Circuit initial conditions

\begin{tabular}{|c|c|c|c|c|}
\hline \multicolumn{5}{|c|}{ Simulation initial values and results } \\
\hline converter & Buck & boost & buck-boost & \\
\hline & P\#1 & P\#2 & P\#5 & \\
\hline Ro & 2.8125 & 80 & 45 & $\Omega$ \\
\hline Co & 0.01 & 100 & 100 & $\mu F$ \\
\hline IEi & $0,5.40,5.26$ & $4 \pm 150 \mathrm{~m}$ & $0,5.66,5.06$ & $A$ \\
\hline ILi & $4 \pm 37.5 \mathrm{~m}$ & $3 \pm 150 \mathrm{~m}$ & $4 \pm 150 \mathrm{~m}$ & $A$ \\
\hline ILo & $1.33 \pm 37.5 \mathrm{~m}$ & $1 \pm 150 \mathrm{~m}$ & $1.33 \pm 150 \mathrm{~m}$ & $\mathrm{~A}$ \\
\hline Vc & $0 \pm 1$ & $0 \pm 3 / 4$ & $0 \pm 1$ & $V$ \\
\hline Vo & $14.99 \pm 0.1$ & $79.95 \pm 75 \mathrm{~m}$ & $59.96 \pm 0.1$ & $V$ \\
\hline lo & $5.33 \pm 36 \mathrm{~m}$ & $1 \pm 1 \mathrm{~m}$ & $1.33 \pm 2 \mathrm{~m}$ & A \\
\hline
\end{tabular}

The six plots of figure 2 show the simulation and experimental time domain results for each of the three converters, operating under the same frequency (fs $=50 \mathrm{kHz})$, duty cycle $(\delta=3 / 4)$, and input conditions $(\mathrm{Ei}=20 \mathrm{~V}$ and $\mathrm{li}=4 \mathrm{~A}$ average, sourcing $80 \mathrm{~W})$. The same electrical components, rearranged, are used in each case.

Basically, in simulation and experimentally, the currents in both inductors and the supply input agree, as does the capacitor voltage ripple, all of which are predicted by the appropriate equations in Table I. Figure 2 also shows that the corresponding simulation and experimental current values agree with awing accurately. That is, the current regulation is good, unlike the voltage regulation which is significantly poorer and deteriorates with increasing input current. These converter regulation features are considered further in the next section.

\section{FURTHER EXPERIMENTAL RESULTS: THREE NEW CONVERTER TOPOLOGIES}

Figure 3 shows the open loop dependence of efficiency, voltage regulation (droop), inductor ripple currents, capacitor voltage and ripple, and output current regulation (droop), on input current average magnitude li. The experimental circuit component values are as shown in Table IIA. Generally, these graphs show that efficiency and voltage regulation deteriorate (near linearly) with increased load/input current. In confirming the inductor ripple current equations in Table I, the ripple current of the inductors is independent of load current - figure 3b. The effects of inductor saturation are observed first in the buck- 
boost and buck converters, before the boost converter, as input current increases, since the buck converter decreases the voltage and increases the output current (hence inductor current) for a given input voltage and current (cf. figure 4b). Figure $3 a$ shows that the boost converter P\#2 is the most efficiency hence has the best output voltage regulation, whilst the buck-boost converter P\#5 has the lowest efficiency, whence the poorest output voltage regulation. Figure $3 \mathrm{~b}$ shows that the buck converter P\#1 has the lowest inductor ripple currents, which is due to the fact that buck circuit voltages are lower than the boost and buck-boost circuit voltages, for a given input voltage $\mathrm{Ei}$ (cf $\mathrm{v}=\mathrm{Ldi} / \mathrm{dt}$ ). Also in accordance with the theory and eqn 1 in figure 1 and table I, the capacitor ripple voltage $\Delta \mathrm{vc}$ in figure $3 \mathrm{c}$ increases linearly with increased load current (for a given $\delta$, etc.). Due to Lo - $\mathrm{Li}-\mathrm{C}$ circuit loop losses, specifically the unequal inductor resistive component voltages, thus not included in the theory, the capacitor has a dc bias, which is duty cycle dependant, and increases with load current, as shown in figure 3c. Important to CCM operation, figure $3 \mathrm{c}$ also shows that the offset voltage tends to zero as the input current, hence output current, approaches zero (that is, no



load). (This bias is not explicitly shown in the $\mathrm{li}=4 \mathrm{~A}$ experimental time domain ac coupled waveforms in figure 2.) Figure $3 \mathrm{~b}$ shows that if the inductances are equal $(\mathrm{Li}=\mathrm{Lo})$, the ripple current magnitudes are equal, whence the two inductors can be wound on a common core (as with the Cuk, sepic and zeta converters) but with ripple current addition (not cancellation), resulting in an accumulated dc flux biases. From Table I, the relative current magnitudes in the two inductor windings, change-over at $\delta=1 / 2$ (the buck to boost boundary).

In contrast to the output voltage regulation, the three converters exhibit good output current regulation characteristics, as shown in figure $3 \mathrm{~d}$. The voltage regulation in figure $3 a$ deteriorates because semiconductor voltages and IR drops detract from the effective input voltage. On the other hand, the current transfer ratio is largely unaffected by voltage components; it is purely a relation between the input and output currents, independent of the input voltage. Hence at the modest input voltage of $20 \mathrm{~V}$, the current regulation is an order of magnitude better than the voltage regulation. Such a regulation feature is common to all dc-to-dc converters.

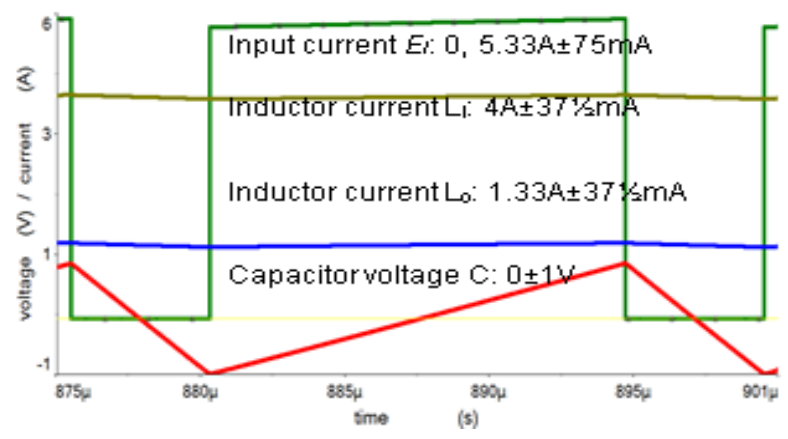

(a) Experimental and simulation buck converter P\#1 waveforms:

inductor and input currents and capacitor voltage for $\mathrm{Vo}=13.8 \mathrm{~V}$, lo $=5.36 \mathrm{~A}, \eta=92.5 \%$.
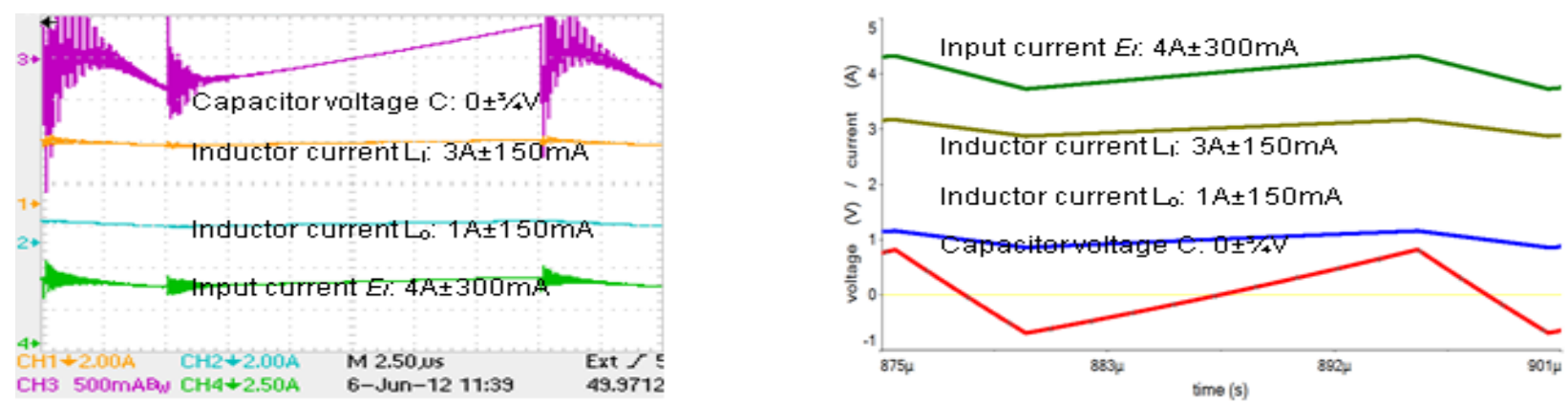

(b) Experimental and simulation boost converter P\#2 waveforms:

inductor and input currents and capacitor voltage for $\mathrm{Vo}=76.4 \mathrm{~V}$, $\mathrm{lo}=0.99 \mathrm{~A}, \eta=94.5 \%$. 

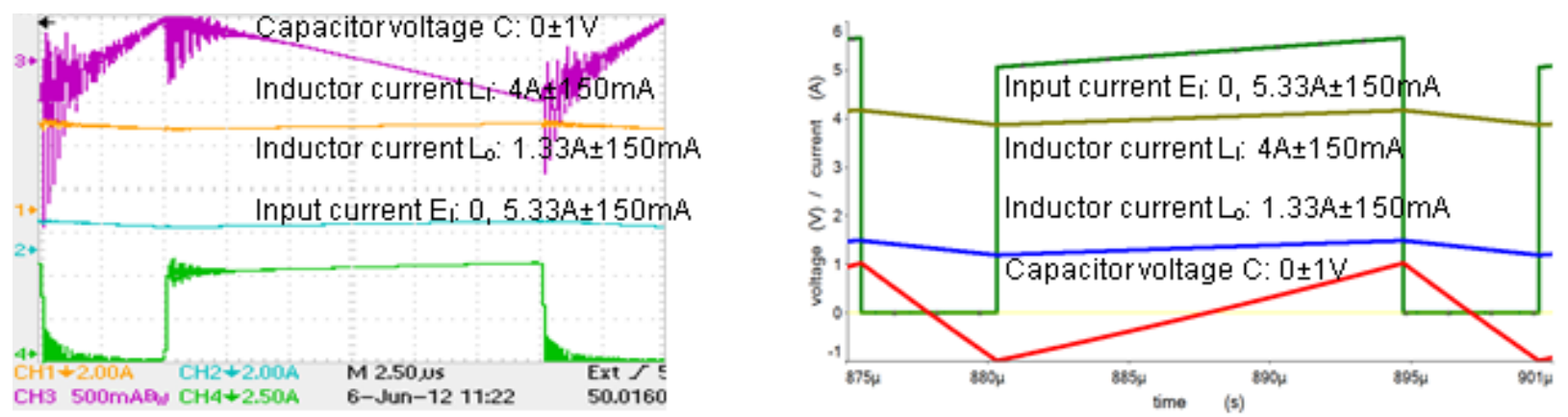

(c) Experimental and simulation buck-boost converter $P \# 5$ waveforms:

inductor and input currents and capacitor voltage for $\mathrm{Vo}=55.1 \mathrm{~V}, \mathrm{lo}=1.32 \mathrm{~A}, \eta=90.9 \%$.

Fig .2. Experimental and simulation results at $50 \mathrm{kHz}, \delta=75 \%$, Ei $=20 \mathrm{~V}$ and $\mathrm{li}=4 \mathrm{~A}$ (ave): $80 \mathrm{~W}$ for:

(a) buck-P\#1, (b) boost-P\#2, and (c) buck-boost-P\#5 converters.

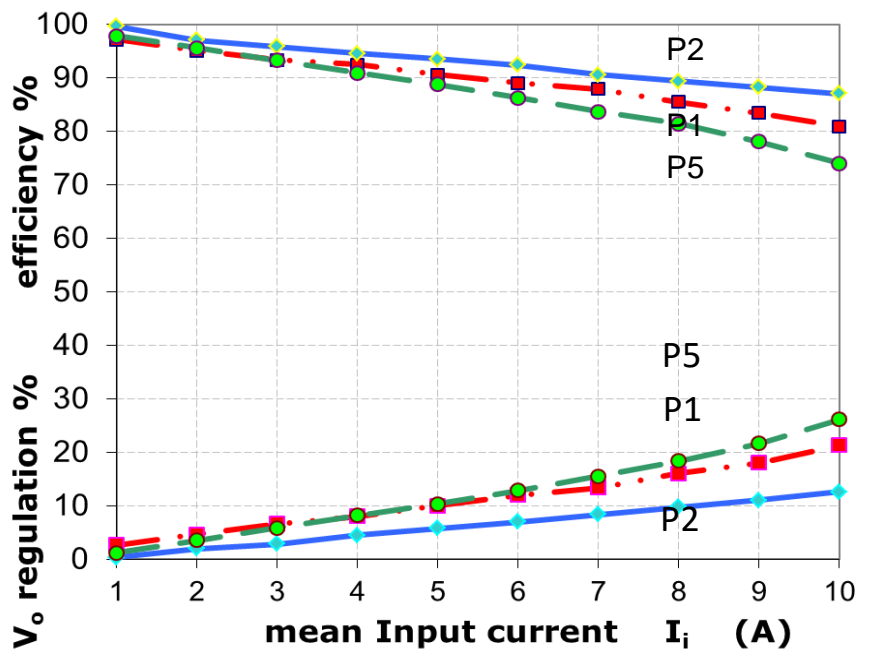

(a) Converters $\mathrm{P} 1 / \mathrm{P} 2 / \mathrm{P} 5, \quad \delta=3 / 4$

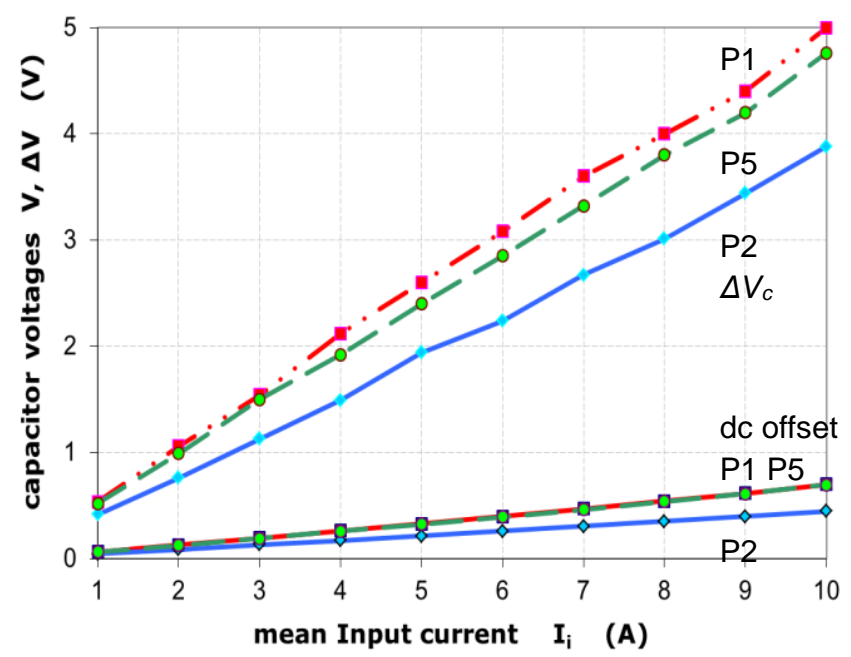

(c) Converters P1/P2/P5, = $3 / 4$



(b) ConvertersP1/P2/P5, $\delta=3 / 4$



Fig .3. Experimental results at $50 \mathrm{kHz}, \delta=75 \%, \mathrm{Ei}=20 \mathrm{~V}$ and varied average input current, for the three new dc-to-dc converters

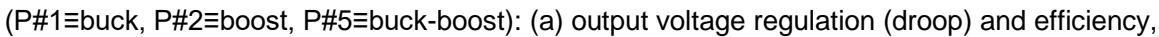

(b) inductor ripple currents, (c) capacitor voltages, and (d) output current regulation (droop). 


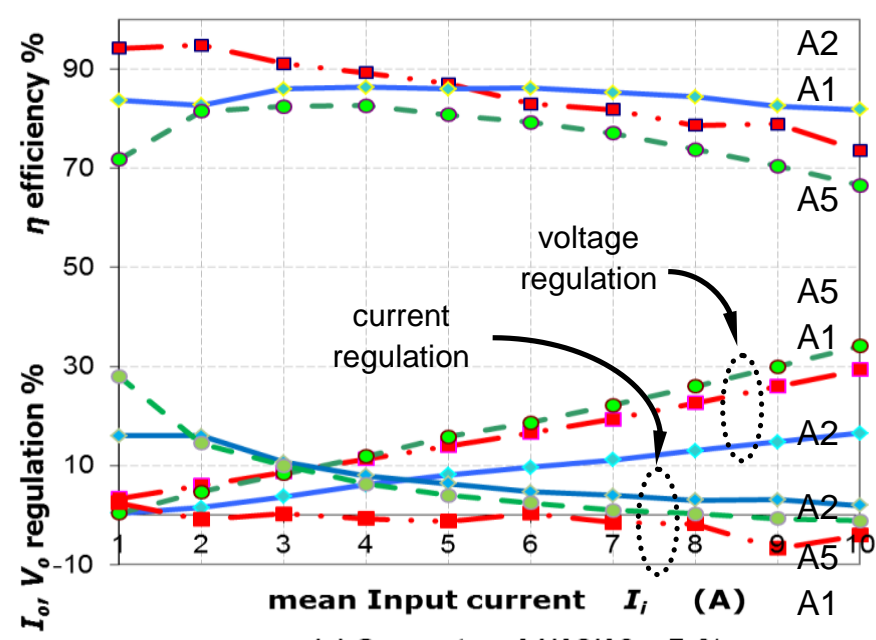

(a) Converters A1/A2/A3, $\delta=3 / 4$

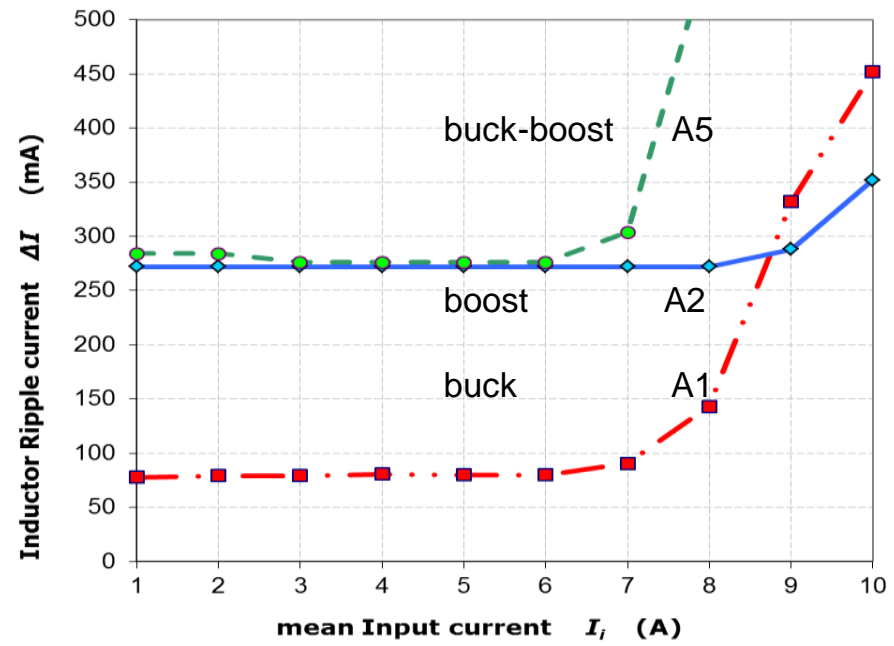

(b) Converters A1/A2/A3, $\delta=3 / 4$

Fig .4. Experimental result for basic single-inductor dc-to-dc converters, A1, A2, and A5:

(a) voltage and current regulation (droop) and efficiency and (b) inductor ripple current.

In the three basic dc-to-dc converters, A1, A2, and A5, inductor ripple current is an indication of minimum load current before loss of CCM operation. In the buck converter P\#1 waveforms (simulation and experimental) in figure $2 \mathrm{a}$, the ripple current is a constant $\pm 371 / 2 \mathrm{~mA}$ (which is the same as for P\#1 in figure $3 b$ and $A 1$ in figure $4 b$ ), which for the basic buck converter $\mathrm{A} 1$ represents a minimum load current of $371 / 2 \mathrm{~mA}$, for CCM. In a light-load case for the new buck converter P\#1, at $100 \mathrm{~mA}(0.01 \mathrm{pu})$ input current, the efficiency is $96.9 \%$, and importantly the output voltage is $14.9 \mathrm{~V}$, representing voltage and current regulation droops of $2.5 \%$ and $0.7 \%$ respectively.

In the case of the buck-boost converter, rearrangement of the basic components, giving the Cuk, sepic and zeta converters, results in similar performance characteristics of efficiency and regulation, as well as ac closed loop performance. The main component difference between the four buck-boost converters is the capacitor dc bias.

\section{EXPERIMENTAL COMPARISON WITH THE THREE BASIC CONVERTER TOPOLOGIES}

The experimental performance characteristics of efficiency, voltage and current regulation and ripple current of the three basic (buck - A1, boost - A2 and buck-boost - A5) [31] converters are shown in figure 4. The three basic converters have a single energy transfer storage element, namely an inductor; regulation would be expected to be poorer than that for the new converters which (like the Cuk, sepic and zeta converters) have more storage elements. Figure 5 compares the characteristics of the basic converters A1, A2, and A5 with the three new converters, P\#1, $\mathrm{P \# 2}$, and P\#5. The boost converter has the best output voltage regulation, whilst the buck-boost converter has the poorest output voltage regulation. The buck converter output current regulation is similar for both buck converters (A1 and P\#1) since the basic buck converter also has inductance in the output, which maintains current regulation. The basic boost and buck-boost converters have poor current regulation because the only inductor is not solely in the output (that is, the inductor is switched between the input and output circuits). Figure $4 \mathrm{~b}$ shows that the inductor current ripple of the three basic converters is similar to the ripple in the new converters, shown in figure $3 \mathrm{~b}$. Inductor saturation at just under $10 \mathrm{~A}$ input is shown in figure $4 \mathrm{~b}$, for the three basic converters. In the boost converter A2, the inductor is in series with the input, hence its current is the input current. The buck and buck-boost converters saturate at less than $10 \mathrm{~A}$ input current, because the inductor average current is not the average input current, but is dependent on duty cycle. Specifically, the basic buck converter inductor current is the output current, which is given by li $/ \delta$, which is always greater than the input current. The same expression applies to the buckboost converter, thus saturation is seen to occur at $\delta x \operatorname{~}(3 / 4 \times 10 A=71 / 2 A)$ in figure $4 b$, for both $A 1$ and $A 5$.

The three new converters are correspondingly more efficient, independent of ripple current. For example, the ripple current of the two buck versions (A1 and $P \# 1)$ is $75 \mathrm{~mA}$ in each case, yet for the same input 
power conditions, the new buck converter $\mathrm{P} \# 1$ is more efficient. The improved efficiency is related to the fact that the effective inductor dc current component is split between two inductors, which significantly decreases the total I2R loss. Specifically for the buck converter $\mathrm{P \# 1}$ in figure $2 \mathrm{a}$, at $4 \mathrm{~A}$ average input current, which gives $51 / 3 \mathrm{~A}$ output current at $\delta=3 / 4$, inductor copper losses are $42 \times 74 \mathrm{~m} \Omega+11 \frac{1}{3} 2 \times 74 \mathrm{~m} \Omega=$ $1.3 \mathrm{~W}$ as opposed to $51 / 32 \times 74 \mathrm{~m} \Omega=2.1 \mathrm{~W}$ with the single inductor buck converter $\mathrm{A} 1$.

Figure 5 shows that the new converters have better performance indicators (efficiency and open loop regulation) than the corresponding basic converters, but inductor ripple current is the same. This performance improvement with the new converters would be expected since the new converters (like the Cuk, sepic and zeta converters) have more energy storage components. From figure $5 \mathrm{c}$, when comparing the basic and new converters, generally voltage regulation becomes poorer with increasing current. The current regulation for the new converters is near independent of current magnitude, while the current regulation is poorer for the basic boost and buckboost converters $\mathrm{A} 1$ and $\mathrm{A} 5$ as the input current decreases.

These comparative performance results, based on figures 3 and 4 , and collated in figure 5 , are summarized in table 3 .

The closed loop design criteria are the same as for the Cuk, sepic and zeta converters, all of which employ two inductors and a capacitor, rearranged. This is because all these topologies have the same ac equivalent circuit.



(a) Converters A1/A2/A3 and P1/P2/P $\delta=\%$

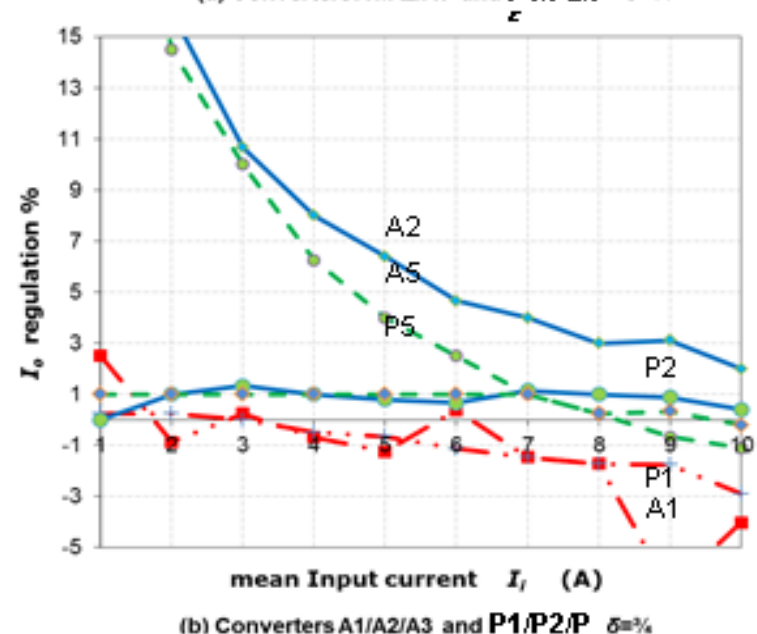

(b) Converters A1/A2/A3 and P1/P2/P $\delta m^{3} / 4$

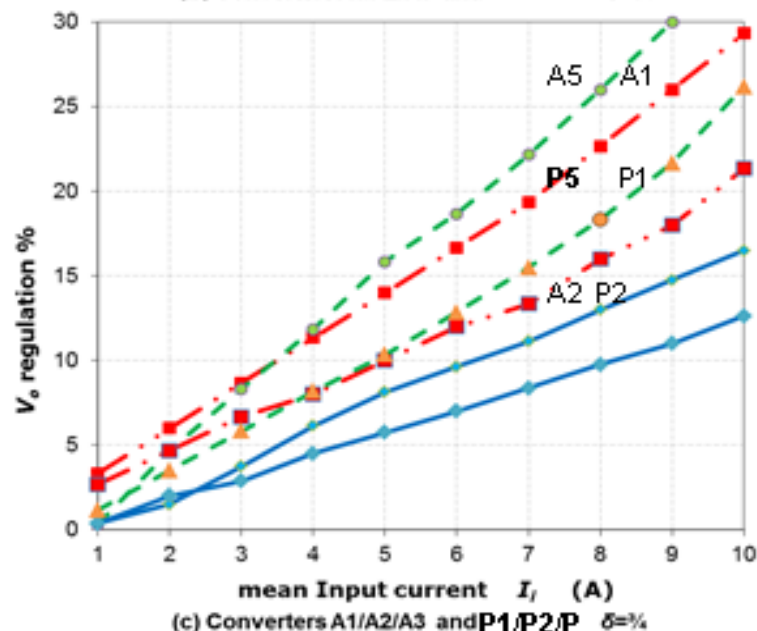

(c) Converters A1/A2/A3 andP1/P2/P $\delta=1 / 4$

Fig .5. Experimental result comparing three basic (A1, A2, A5) and three new dc-to-dc converters (P\#1, P\#2, P\#5):

(a) efficiency, (b) output current regulation (droop), and (c) output voltage regulation (droop). 

http://dx.doi.org/10.21622/RESD.2017.03.2.196

Table 3. Comparison of operational properties and characteristics (at $\delta=3 / 4$ ).

\begin{tabular}{|c|c|c|c|c|c|c|}
\hline & \multicolumn{6}{|c|}{ CONVERTERS } \\
\hline & \multicolumn{3}{|c|}{$\begin{array}{l}\text { Basic converters } \\
\text { (one inductor) }\end{array}$} & \multicolumn{3}{|c|}{$\begin{array}{c}\text { New converters } \\
\text { (two inductors and one capacitor) }\end{array}$} \\
\hline transfer function & buck & boost & buck-boost & buck & boost & buck-boost \\
\hline classification & A1 & A2 & A5 & P\#1 & P\#2 & P\#5 \\
\hline efficiency & $\begin{array}{l}\text { Less than P1 } \\
\text { Better than A5 }\end{array}$ & $\begin{array}{l}\text { Less than P2 } \\
\text { Better than A5 }\end{array}$ & $\begin{array}{l}\text { Less than P5 } \\
\text { Poorer than } \\
\text { A1 and A5 }\end{array}$ & $\begin{array}{l}\text { Better than A1 } \\
\text { Better than P5 }\end{array}$ & $\begin{array}{l}\text { Better than A2 } \\
\text { Better than } \\
\text { P1 and P5 }\end{array}$ & $\begin{array}{l}\text { Better than A5 } \\
\text { Poorer than } \\
\text { and P5 }\end{array}$ \\
\hline $\begin{array}{l}\text { output voltage } \\
\text { regulation }\end{array}$ & $\begin{array}{l}\text { Better than A5 } \\
\text { Poorer than P1, } \\
\text { P2, and P5 }\end{array}$ & $\begin{array}{l}\text { Better than } \mathrm{A} 1 \\
\text { and A5 } \\
\text { Better than } \\
\text { P1 and P5 }\end{array}$ & $\begin{array}{l}\text { Worse than } \mathrm{A} 1 \\
\text { and } \mathrm{A} 2 \\
\text { Poorer than P1, } \\
\text { P2, and P5 }\end{array}$ & $\begin{array}{l}\text { Better than P5 } \\
\text { Better than } \\
\text { A1 and A5 }\end{array}$ & $\begin{array}{l}\text { Better than } \mathrm{P} 1 \\
\quad \text { and } \mathrm{P} 5 \\
\text { Better than } \mathrm{A} 1 \text {, } \\
\text { A2 and A5 }\end{array}$ & $\begin{array}{c}\text { Worse than } \mathrm{P} 1 \text { and } \mathrm{P} 2 \\
\text { Better than } \\
\text { A1 and A5 }\end{array}$ \\
\hline $\begin{array}{l}\text { output current } \\
\text { regulation }\end{array}$ & $\begin{array}{l}\text { Similar to P1 } \\
\text { Better than } \\
\text { A1 and A2 }\end{array}$ & $\begin{array}{l}\text { Poorer than P2 } \\
\text { poorer than } \\
\text { A1 and A5 }\end{array}$ & $\begin{array}{l}\text { Poorer than P5 } \\
\text { Poorer than A1 }\end{array}$ & $\begin{array}{l}\text { Similar to A1 } \\
\text { Similar to } \\
\text { P2 and P5 }\end{array}$ & $\begin{array}{l}\text { Better than A2 } \\
\text { Slightly better } \\
\text { than P1 }\end{array}$ & $\begin{array}{c}\text { Better than A5 } \\
\text { Slightly better than } \mathrm{P} 1\end{array}$ \\
\hline ripple current & $\begin{array}{l}\text { Same as P1 } \\
\text { Less than } \\
\text { A2 and A5 }\end{array}$ & $\begin{array}{l}\text { Similar to P2 } \\
\text { Similar to } \\
\text { A2 and A5 }\end{array}$ & $\begin{array}{l}\text { Similar to P5 } \\
\text { Similar to } \\
\text { A2 and A5 }\end{array}$ & $\begin{array}{l}\text { Same as A1 } \\
\text { Less than } \\
\text { P2 and P5 }\end{array}$ & $\begin{array}{l}\text { Similar to A2 } \\
\text { Similar to P5 }\end{array}$ & $\begin{array}{l}\text { Similar to A5 } \\
\text { Similar to P2 }\end{array}$ \\
\hline
\end{tabular}

\section{TRANSFORMER ISOLATED BUCK-BOOST CONVERTER}

The basic buck-boost converter A3 output can be isolated via a coupled magnetic circuit. Additional features to isolation are voltage matching and better semiconductor utilization, but the limitation is that energy is temporarily stored in the magnetic coupled circuit core. Thus for a given magnetic material, maximum energy transfer is limited by core volume, viz. $1 / 2 \mathrm{BH} \times$ Volume. The core volume is utilized differently if magnetic energy transfer is through transformer action (as with the Cuk converter variation) rather than intermediate energy storage (as for the basic buck-boost converter variation).

If energy is transferred from the source to the load via ripple current through a series capacitor, then that capacitor can be split so as to facilitate an interposed high magnetizing inductance shunt transformer as shown in figure 6 . If electrical equivalence is maintained, each capacitor has the same capacitance as the original capacitor, if the transformer turns ratio is 1:1. This is the process used for the transformer isolated Cuk converter, with a buck-boost voltage transfer function, which fulfills the series energy transfer capacitor requirement. The transformer acts in a current controlled mode where the voltage adjusts to meet the corresponding voltage requirement associated with the transformer equation (lin / lout = Vout $/$ Vin = Nout $/$ Nin) together with the converter current/voltage transfer function (li / lo $=\mathrm{Vo} / \mathrm{Ei}=-\delta /$ $1-\delta)$, both enforced since both equations must comply with instantaneous energy conservation. This operation is not to be confused with the problematic so called 'verge of coupled circuit and transformer operation'. In the Cuk converter case the split capacitor pair must also fulfill the important function of blocking a dc voltage component (Ei on the primary, Vo on the secondary) from the magnetic coupling circuit, which is catered for, blocked, by using large capacitance. The new buck-boost converter P\#5 theoretically develops no dc voltage component on the primary or the secondary, because each is in parallel with inductance, which has zero average 
voltage. In practice, any dc voltage bias is modified (increased) due to component voltage drops, including inductor and transformer winding resistance associated voltages.

The energy transferred is the load power Vo lo over the switching cycle period $\mathrm{T}$, which is related to the change in energy in the primary and secondary capacitors $\mathrm{Cp}$ and $\mathrm{Cs}$. From eqn 1 in figure 1, for the buck-boost converter, the capacitor ripple voltage is given by

$$
\begin{aligned}
\Delta v_{c} & =\frac{t_{o n} \times I_{o}}{C}=\frac{\left(\tau-t_{o n}\right) \times I_{i}}{C} \\
& =\delta \frac{I_{o} \tau}{C}=(1-\delta) \frac{I_{i} \tau}{C}
\end{aligned}
$$

Therefore the capacitor $\mathrm{dv} / \mathrm{dt}$ requirement is

$$
\frac{\Delta v_{c}}{\Delta t_{\text {on }}}=\frac{I_{o}}{C} \quad \frac{\Delta v_{c}}{\Delta t_{\text {off }}}=\frac{I_{i}}{C}
$$

Energy is transferred in a single direction through the transformer: the voltage polarities change depending on whether the capacitors are charging or discharging, but with zero average current. Since the capacitors in P\#5 have a zero average-voltage requirement, that is, do not need significant dc blocking capability, the capacitance is dimensioned based on $\mathrm{dv} / \mathrm{dt}$ restrictions (as opposed to average voltage values in addition to superimposed $\mathrm{dv} / \mathrm{dt}$ limitations as with the Cuk, sepic and zeta converters). Capacitance transfers transformer sides in the turns ratio, inverse squared (Xca1/C).

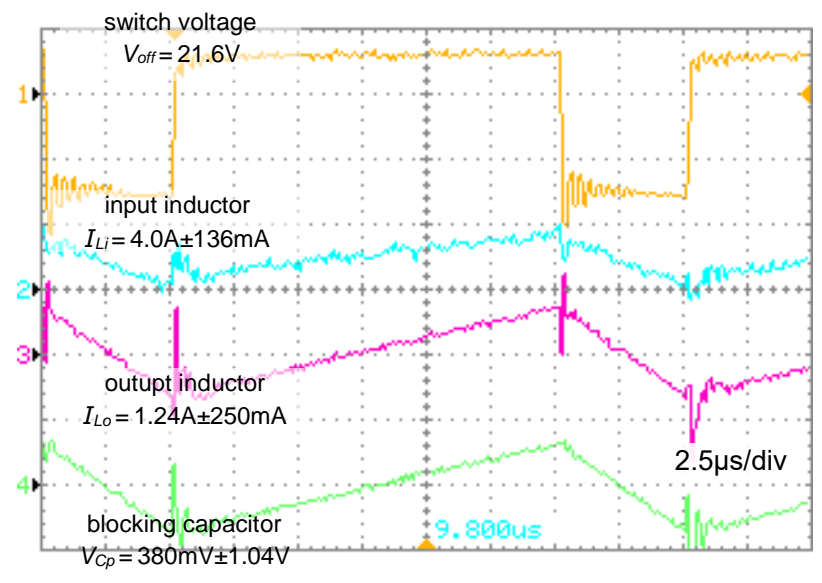

Figure 7 shows time domain simulation and practical results, which confirm the mechanisms proposed, when the component values are as used for assessment of the three converters, in table IIA. The series energy transfer capacitors are both $10 \mu \mathrm{F}$ and the transformer has a 1:1 turns ratio. The practical results yield $80.5 \%$ efficiency at $80 \mathrm{~W}$ input, falling to $70 \%$ efficiency at rated $(200 \mathrm{~W}) 10 \mathrm{~A}$ input, for the given duty cycle, $\delta=3 / 4$. The capacitor dc offset of $380 \mathrm{mV}$ at $4 \mathrm{~A}$ and $1.2 \mathrm{~V}$ at $10 \mathrm{~A}$, implies Joule losses consistent with $110 \mathrm{~m} \Omega$ resistance in the transformer (primary and secondary) and inductor $(74 \mathrm{~m} \Omega)$, plus switch $(54 \mathrm{~m} \Omega$ ) loops. An RCD snubber or a transient surge suppressor ( $<1 \mathrm{~W}$ for $20 \mathrm{~V}, 10 \mathrm{~A}$ input) is essential to preventing excessive switch voltages at turn-off due to transformer leakage inductance $(\approx 200 \mathrm{nH})$ related trapped magnetic energy. Differences between the experimental and simulation results are due to the simulation models not accounting for switching losses, capacitor tan $\delta$, and transformer leakage inductance losses and effects.

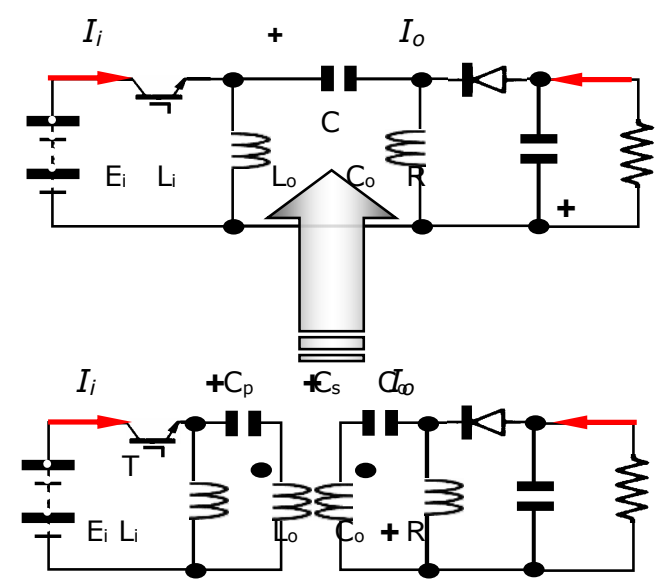

Fig .6. New dc-to-dc buck-boost converter P\#5 conversion to transformer coupled version.

output voltage

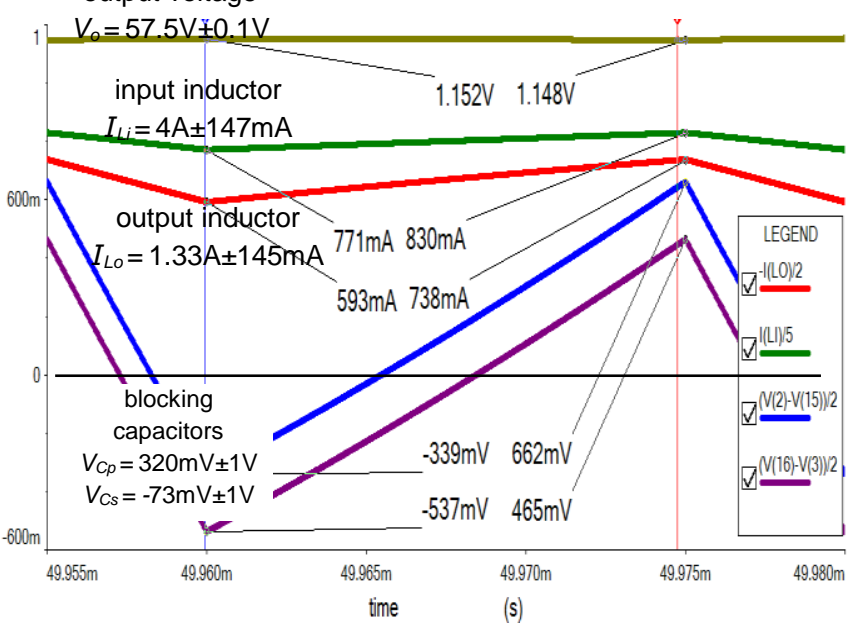

Figure 7. Simulation and experimental results for the transformer coupled buck-boost converter P\#5,

at $20 \mathrm{Vdc}, 4 \mathrm{~A}$ ave $(80 \mathrm{~W})$ input, $\eta=80.5 \%$ (output $51.9 \mathrm{Vdc}, 1.24 \mathrm{~A}$ ). 


\section{CONCLUSIONS}

Three new dc-to-dc converters (buck - P\#1, boost P\#2, and buck-boost - P\#5) have been presented. Like the Cuk, sepic, Luo and zeta converters, the disadvantage of the three new converters is that an extra capacitor and inductor are needed, compared to the three basic dc-to-dc converters (A1, A2, and A5). The advantages gained by the extra passive energy storage components, as with the Cuk, sepic and zeta converters, are better efficiency and output voltage and current regulation.

Analysis wise, the new circuit topologies degenerate to the equivalent basic converter with the same voltage transfer function (A1, A2, and A5). The interesting features of the new converters are associated with the fact that the three topologies have zero average capacitor voltage. Unlike the Cuk, sepic and zeta converters, capacitor stressing is solely limited to $\mathrm{dv} / \mathrm{dt}$ stressing, without a dc component. This property is best exploited in a transformer isolated version with a buck-boost transfer function, $\mathrm{P \# 5}$, where the split capacitors have zero average voltage, that is, zero dc blocking voltage requirements, unlike the split capacitor transformer isolated Cuk converter. This new topology has been validated by simulation and 20V, 200W experimentation, and is suitable for fuel cell, battery, and PV module isolated interfacing.

\section{REFERENCES}

[1] F. Nejabatkhah , S. Danyali, S.H. Hosseini , M. Sabahi and S.M. Niapour. "Modeling and control of a new three-input DC-DC boost converter for hybrid PV/FC/battery power system.", IEEE Transactions on Power Electronics, vol. 27pp. 2309-2324, 2012.. DOI: 10.1109/TPEL.2011.2172465

[2] R.K. Singh. and S.A. Mishra. "Magnetically coupled feedback-clamped optimal bidirectional battery charger." , IEEE Transactions on Industrial Electronics, vol. 60, issue2 pp. 422432, 2013. DOI: 10.1109/TIE.2012.2186776

[3] H. Tai-Sik , M.J. Tarca and P. Sung-Yeul. "Dynamic response analysis of DC-DC converter with supercapacitor for direct borohydride fuel cell power conditioning system." IEEE Transactions on Power Electronics, vol. 27, pp. 3605-3615,2012.DOI:

10.1109/TPEL.2012.2185711

[4] H. Tai-Sik and P. Sung-Yeul . "Seamless boost converter control under the critical boundary condition for a fuel cell power conditioning system." IEEE Transactions on Power Electronics, vol. 27, pp. 3616-3626., 2012. DOI: 10.1109/TPEL.2012.2185250

[5] H. Tai-Sik , M.J. Tarca, and P. Sung-Yeul . "Dynamic response analysis of DC-DC converter with supercapacitor for direct borohydride fuel cell power conditioning system." IEEE Transactions on Power Electronics, vol. 27, pp. 3605-3615., $2012 . \quad$ DOI: 10.1109/TPEL.2012.2185711

[6] C.N. Ho, H. Breuninger, S. Pettersson, G. Escobar, L.A. Serpa and A. Coccia. "Practical design and implementation procedure of an interleaved boost converter using SiC Diodes for PV applications." IEEE Transactions on Power Electronics, vol. 27, pp. 2835-2845, 2012.DOI: 10.1109/TPEL.2011.2178269

[7] F. Locment, M. Sechilariu and I. Houssamo . "DC load and batteries control limitations for photovoltaic systems. Experimental validation." IEEE Transactions on Power Electronics, vol. 27, pp. 4030-4038., $2012 . \quad$ DOI: 10.1109/TPEL.2012.2189134

[8] Z. Zheng, X. Ming, C. Qiaoliang, L. Jih-Sheng and C. Younghoon. "Derivation, analysis, and implementation of a boost-buck converter-based high-efficiency PV inverter." IEEE Transactions on Power Electronics, vol. 27, pp. 1304-1313, 2012. DOI: 10.1109/TPEL.2011.2163805

[9] L. Yu-Huei , H. Shao-Chang, W. Shih-Wei, W. Wei-Chan, H. Ping-Ching, H. Hsin-Hsin, L. YuanTai and C. Ke-Horng ."Power-tracking embedded buck-boost converter with fast dynamic voltage scaling for the SoC system." IEEE Transactions on Power Electronics, vol. 27, pp. $2012.271-1282 . \quad$ DOI: 10.1109/TPEL.2010.2101085

[10] S. Vighetti, J.P. Ferrieux and Y. Lembeye . "Optimization and design of a cascaded DC/DC converter devoted to grid-connected photovoltaic systems." IEEE Transactions on Power Electronics, vol. 27, pp. 2018-2027, 2012.

DOI: 10.1109/TPEL.2011.2167159

[11] W. Li, and X. He. "Review of non-isolated highstep-up DC/DC converters in photovoltaic gridconnected applications." IEEE Transactions on Industrial Electronics, vol. 58, pp. 1239-1250. 2011, DOI: $10.1109 /$ TIE.2010.2049715 
[12] Y.P. Hsieh, J.F. Chen, T.J. Liang, and L.S. Yang. "Novel high step-up DC-DC converter for distributed generation system." IEEE Transactions on Industrial Electronics, vol. 60, pp. 1473-1482, 2013, DOI: 10.1109/TIE.2011.2107721

[13] S. Vighetti, J.P. Ferrieux and Y. Lembeye ."Optimization and design of a cascaded DC/DC converter devoted to grid-connected photovoltaic systems'."IEEE Transactions on Power Electronics, vol. 27, pp. 2018-2027, 2012.

DOI: 10.1109/TPEL.2011.2167159

[14] A.V. Stankovic, L. Nerone andP. Kulkarni."Modified synchronous-buck converter for a dimmable HID electronic ballast." IEEE Transactions on Industrial Electronics, vol. 59, pp. 1815-1824, 2012. DOI: 10.1109/TIE.2011.2141094

[15] A. Richelli, S. Comensoli and Z.M. KovacsVajna. "A DC/DC boosting technique and power management for ultralow-voltage energy harvesting applications." IEEE Transactions on Industrial Electronics, vol. 59, pp. 2701-2708, 2012. DOI: $10.1109 /$ TIE.2011.2167890

[16] II-Oun L, Shin-Young C, Gun-Woo M, 'Interleaved Buck Converter having Low Switching Losses and Improved Step-Down Conversion Ratio', IEEE Transactions on Power Electronics, Vol. 27, Issue 8, 2012. pp. 36643675.

DOI: 10.1109/TPEL.2012.2185515

[17] L. Il-Oun , C. Shin-Young and M. Gun-Woo. "Interleaved buck converter having low switching losses and improved step-down conversion ratio." IEEE Transactions on Power Electronics, vol. 27, pp. 3664-3675, 2012.

DOI: 10.1109/TPEL.2012.2185515

[18] R.F. Foley, R.C. Kavanagh and M.G. Egan. "Sensorless current estimation and sharing in multiphase buck converters', IEEE Transactions on Power Electronics, vol. 27, pp. 2936-2946, 2012. DOI: 10.1109/TPEL.2010.2042072

[19] A.J. Forsyth and G. Calderon-Lopez. "Sampleddata analysis of the dual-interleaved boost converter with interphase transformer." IEEE Transactions on Power Electronics, vol. 27, pp. 1338-1346, 2012.2 DOI: 10.1109/TPEL.2011.2163645
[20] J.Y. Lee, Y.S. Jeong and B.M. Han. "A twostage isolated/bidirectional $D C / D C$ converter with current ripple reduction technique." IEEE Transactions on Industrial Electronics, vol. 59, pp. 644-646, 2012. DOI: 10.1109/TIE.2011.2109343

[21] L.S. Yang and T.J. Liang. "Analysis and implementation of a novel bidirectional DC-DC converter.", IEEE Transactions on Industrial Electronics, vol. 59, pp. 422-434, 2012. DOI: 10.1109/TIE.2011.2134060

[22] W. Hongfei, L. Juejing, S. Wei and X. Yan X. "Non-isolated bidirectional DC-DC converters with negative-coupled inductor." IEEE Transactions on Power Electronics, vol. 27, pp, 2231-2235., 2012.2 DOI: 10.1109/TPEL.2011.2180540

[23] Z. Honglin, X. Shuai, Y. Geng and G. Hua. "Modeling and control for a bidirectional buckboost cascade inverter." IEEE Transactions on Power Electronics, vol. 27, pp. 1401-1413, 2012. DOI: 10.1109/TPEL.2010.2103957

[24] P. Patra, A. Patra and N. Misra. "A singleinductor multiple-output switcher with simultaneous buck, boost, and inverted outputs', IEEE Transactions on Power Electronics, vol. 27, pp. 1936-1951, $2012 . \quad$ DOI: 10.1109/TPEL.2011.2169813

[25] Y. Dongsheng, Y. Min $Y$ and R. Xinbo. "Onecycle control for a double-input DC/DC converter." IEEE Transactions on Power Electronics, vol. 27, pp. 4646-4655, 2012. DOI: 10.1109/TPEL.2011.2164582

[26] W. Rong-Jong, L. Chung-You and C. Bo-Han C. "High-efficiency DC-DC converter with two input power sources." IEEE Transactions on Power Electronics, vol. 27, pp. 1862-1875, 2012. DOI: 10.1109/TPEL.2011.2170222

[27] T.J. Liang, J.H. Lee, S.M. Chen, J.F. Chen and Yang L-S. "Novel isolated high-step-up DC-DC converter with voltage lift." IEEE Transactions on Industrial Electronics, vol. 60, pp: 1483 - 1491, 2013. : 10.1109/TIE.2011.2177789

[28] A. Elasser and D.A. Torrey. "Soft switching active snubbers for dc/dc converters." IEEE Transactions on Power Electronics, vol. 11, pp. 710-722, 1996. DOI: 10.1109/63.535403 
[29] N. Kondrath, N and M.K. Kazimierczuk. "Comparison of wide- and high-frequency dutyratio-to-inductor-current transfer functions of DCDC PWM buck converter in CCM." IEEE Transactions on Industrial Electronics, vol. 59, pp: 641-643., 2012, DOI: 10.1109/TIE.2011.2134053

[30] C. Restrepo, J. Calvente, A. Romero, E. VidalIdiarte and Giral R.: Current-mode control of a coupled-inductor buck-boost DC-DC switching converter." IEEE Transactions on Power Electronics, vol. 27, pp. 2536-2549, 2012. DOI: 10.1109/TPEL.2011.2172226
[31] R. Tymerski and V. Vorperian. "Generation and classification of PWM DC-to-DC converters." IEEE Transactions on Aerospace and Electronic Systems, vol. 24, no. 6, pp. 743-754, November 1988.DOI: $10.1109 / 7.18641$ 